\title{
Voters Use Campaign Finance Transparency and Compliance Information
}

\author{
Abby K. Wood ${ }^{1}$ (D) \\ Accepted: 20 January 2022 \\ (C) The Author(s) 2022
}

\begin{abstract}
Campaign finance compliance and transparency reveal important non-policy attributes that voters care about. Using vignette and conjoint survey experiments, I show that voters in primary elections incorporate transparency and compliance considerations into candidate selection. This effect persists even where the candidate shares the respondents' preferred policy positions. The findings bring campaign finance transparency and compliance into the scholarly conversation about candidate valence. They also have implications for our campaign finance jurisprudence and suggest that courts should expand their understanding of the informational benefits of campaign finance disclosures and compliance information.
\end{abstract}

Keywords Transparency · Campaign finance $\cdot$ Valence $\cdot$ Elections · Voting · Compliance

\section{Introduction}

Do voters care about campaign finance transparency? Primary candidates seem to think they do. Candidates from Donald Trump to Elizabeth Warren have rejected support from so-called "dark money" groups during primary elections. But they accept (or planned to accept) their support in the general election. As the studies presented here show, voters care about campaign finance transparency. They use information about campaign finance transparency and compliance to inform their candidate choices.

Campaign financing has changed enormously since 2010. One of the biggest changes is the rise of "dark money," or political spending that happens without any disclosure. Many political actors and messages remain anonymous (Dowling \& Wichowsky, 2013, 2015; Ridout et al., 2015; Rhodes et al., 2019). At the

Abby K. Wood

awood@law.usc.edu

1 Gould School of Law, University of Southern California, 699 Exposition Blvd, Los Angeles,

CA 90089, USA 
same time, the Supreme Court's jurisprudence centers the informational benefits of campaign finance disclosure when considering constitutional challenges to disclosure laws (Wood, 2018).

Even if voters prefer more transparent candidates, will they abandon transparent candidates in favor of candidates whose policy positions they prefer? Political scientists have studied various aspects of this question, but never all at once. For example, many studies analyzing voter learning suggest that voters use campaign finance information to inform their vote choices. For example, Lupia (1994) shows voters use campaign finance information as a heuristic. Spencer and Theodoridis (2020) and Brown and Martin (2015) manipulate the amounts contributed and their sources. Dowling and Wichowsky $(2013,2015)$ randomize disclaimers and media writeups about funding sources. Rhodes et al. (2019) provide respondents information about disclosure itself. While a few studies include political party in the information treatment, none provides policy preferences for respondents to consider. Where campaign finance transparency is a focus of prior studies, those studies stop their exploration at the boundaries of the law, presenting options that are all legally compliant-even if some, such as dark money support, are distasteful to voters.

But campaign finance compliance problems are common (Wood \& Grose, 2021). Studies of voter reactions to candidate compliance problems are rare in the literature, outside of research on scandal (e.g., Basinger et al., 2014). Recent work suggests, however, that voters care about campaign finance compliance: when random FEC audits revealed noncompliance with campaign finance laws, incumbents lost support in a subsequent election (Wood \& Grose, 2021, see also Gaskins et al., 2019).

Finally, no study on candidate transparency incorporates the interaction between policy issues, transparency, and compliance that voters face when a "clean" candidate has less-preferred issue positions, or when a highly preferred candidate on the policy dimension is less transparent or compliant than the voter would like. Studies of policy-valence interactions use broader measures of valence than campaign finance transparency, study party rather than policy, or both (Franchino \& Zucchini, 2015; Kirkland \& Coppock, 2017; Rhodes et al., 2019).

This project narrows the gap in the literature by varying candidate policy, transparency, compliance, and valence characteristics and asking respondents to choose their preferred candidates. The results suggest that information about campaign finance transparency and compliance affects voters' choices, even where voters know candidate policy positions. Respondents are less likely to say they will vote for a politically attractive, but non-transparent, primary candidate if that candidate violates campaign finance rules. They are more likely to say they will vote for primary candidates who discourage "dark money" support, and they consider more transparent candidates to be more trustworthy.

The results have important implications for the scope of the so-called "information benefit" the Supreme Court uses to uphold disclosure laws. Despite its deregulatory approach to campaign finance regulation, the Court has still generally upheld mandatory disclosure regulations on an assumption that the disclosed information improves voter competence by helping voters to know about the kinds of policies a candidate will pursue once in office. These results suggest campaign finance 
transparency and compliance information also reveal valuable information to voters about non-policy candidate traits.

\section{Campaign Finance Transparency and Compliance}

In a general election between candidates from different parties, a candidate's political party is a more powerful heuristic than campaign finance disclosure (Rhodes et al., 2019) and more powerful than broad valence characteristics (Kirkland \& Coppock, 2017; Page \& Jones, 1979). But many elections do not feature candidates from opposing parties. Consider party primary elections, ballot initiatives, and elections in states dominated by one party that have top-two primaries. Without party identification as an available shortcut, voters in these elections must use other cues, including the candidate's personal characteristics, endorsements, and campaign financing, to inform their choice. Policy differences between candidates are reduced where the candidates are from the same party, so transparency and compliance-related evaluations should be particularly salient in primary elections. Nonpartisan general elections have a similar informational deficit, though only the primary setting is tested here. Allegations of dark money arise in campaigns lacking partisan cues. Consider mayoral races large (Miami-Dade, Florida), medium (Charleston, South Carolina), and small (Holland, Michigan); primary races for state legislatures in Florida, and nonpartisan judicial races, especially in Wisconsin (Appendix 1).

Campaigns and their outside groups can exploit the gaps in campaign finance laws to campaign anonymously (Wood \& Ravel, 2018), or they can signal their attitude toward transparency by over-complying and campaigning transparently even where the law does not require it. Voters may react to candidate choices in this realm, possibly even using the candidate's signals as a voting heuristic.

Policy aside, voters want elected officials to be competent, persuasive, and honest. These non-policy candidate and campaign traits are considered "valence" traits (Bianco, 1994; McCurley \& Mondak, 1995; Mondak 1995; Stokes, 1963; Stone \& Simas, 2010). Valence traits are non-policy characteristics voters seek to maximize, regardless of party (Ansolabehere \& Snyder, 2000; Wittman, 2005, Simas, 2021. Some valence traits are more campaign-oriented (e.g., fundraising, persuasiveness) and some are character-oriented (e.g., grasping the issues, competence) (Stone \& Simas, 2010). Campaign finance transparency bridges the gap between campaign valence and character valence. It is a campaign compliance activity voters may also perceive as a proxy for competence or honesty.

Campaign transparency provides information about aspiring rulers to the ruled (Roelofs, 2019). While some campaign transparency is required by law, transparency and legal compliance are separate concepts. The legality of a given level of transparency depends on laws governing the jurisdiction. As legal requirements vary across space and time, campaign choices could be high or low transparency and high or low compliance. Table 1 provides examples of ways campaigns may signal high or low transparency and how compliance is implicated. High transparency and overcompliance, and low transparency and non-compliance are intuitively related. Campaigns can also be legally compliant and have low transparency where the law does 


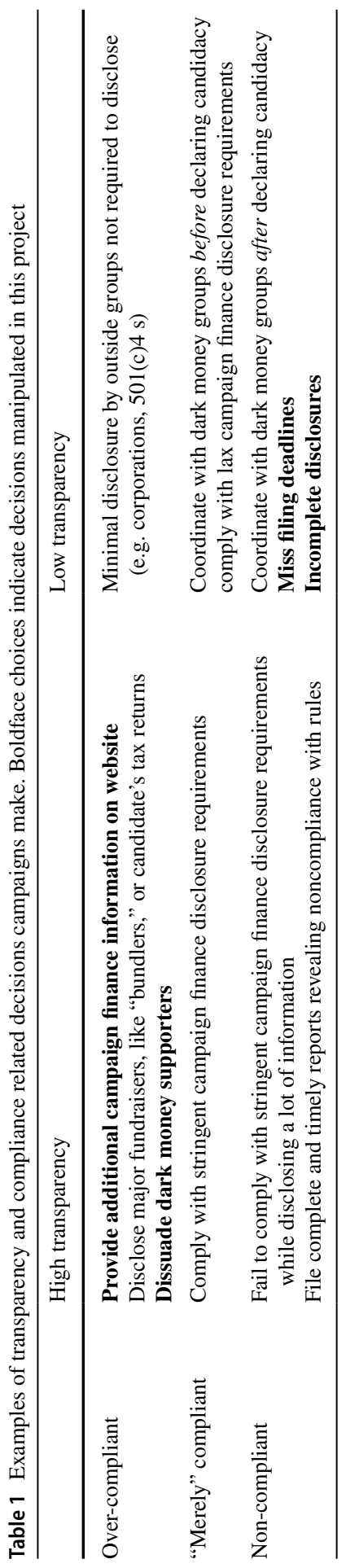


not mandate much disclosure. Common examples are receiving "dark money" support or not releasing a candidate's tax returns. Whether "mere" compliance is high or low transparency depends on legal requirements. Campaigns can even have high transparency and low compliance where a jurisdiction's transparency laws demand too much, and candidates fall short of legal requirements but still disclose a lot of helpful information.

Few scholars have analyzed voter preference around candidate legal compliance generally, compliance with campaign transparency rules specifically, or voluntary transparency (over-compliance) of any kind. Wood and Grose (2021) find that incumbents with campaign finance compliance problems revealed through the FEC's random compliance audit program suffered reduced vote share in the subsequent election. Other scholars have written about scandals, which can result when campaign rules are violated, but which also emerge in myriad other ways (Basinger et al., 2014).

Campaign finance disclosure provides a rare opportunity for a campaign to signal to voters how transparently the candidate will govern and their willingness to comply or over-comply with legal requirements. Several scholars have studied campaign transparency, often using advertising disclaimers (Dowling \& Wichowsky, 2013, 2015; Ridout et al. 2015, Rhodes et al., 2019). However, compliance is not a focus of these studies. If the candidate's disclosures are lacking, perhaps because they are filed late, contain prohibited contributions, or have gaps in required information, voters may infer that the candidate is incompetent, does not prioritize transparency, or is hiding something. If candidates are supported by dark money groups-which does not violate the law-voters may infer that the candidate has something to hide. This leads to my "punishment" hypothesis:

H1a Punishment for lack of transparency: Voters will be less likely to vote for lower-transparency candidates compared to candidates with higher transparency.

H1b Punishment for noncompliance: Voters will be less likely to vote for noncompliant candidates, compared to "merely" compliant candidates.

For any given set of proposed policies, voters should prefer a candidate who signals that she will govern openly by being more transparent during her campaign. ${ }^{1}$ Moreover, for a given set of proposed policies, voters will prefer a candidate who they believe will comply with the law. In addition to rule of law and other highminded considerations, voter concern with compliance is pragmatic: legal compliance avoids scandal and enables governance to proceed more smoothly. This leads to my "reward" hypothesis:

\footnotetext{
1 An anonymous reviewer disagreed with this assumption behind H2 (pre-registered before Study 2), proposing that voters may view over-compliance as a lack of strategic thinking. This is an interesting avenue for future work.
} 
Fig. 1 Percent of 2000 respondents who responded "Important" or "Very Important"; "Moderately Important"; or "Unimportant" or "Of Little Importance" to the question "When you think about the strength of a candidate for elected office, how important to you are the following considerations?" Source CCES 2015

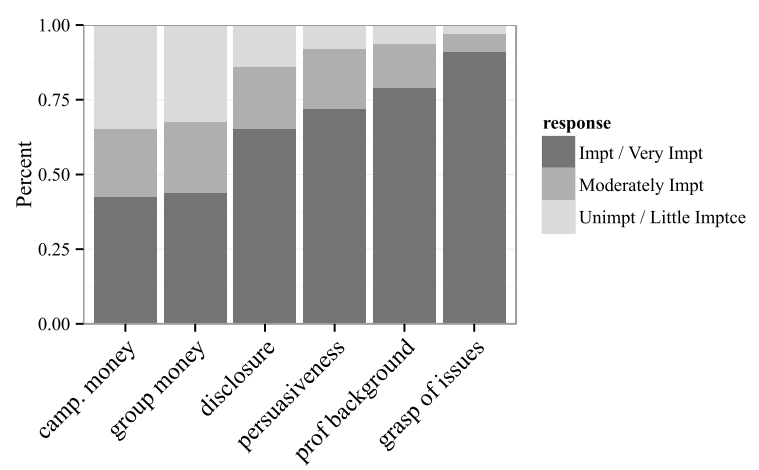

2a Reward for transparency: Voters will prefer candidates who demonstrate high transparency compared to those who do not.

2b Reward for over-compliance: Voters will prefer candidates who over-comply compared to those who "merely" comply.

I test punishment (H1) and reward (H2) separately because of documented asymmetries between reward and punishment (Fehr \& Gachter, 2000; c.f. Wang \& Leung, 2010).

\section{Disclosure and Compliance as Valence Information}

Disclosure and compliance may provide information on a non-policy, or "valence", dimension, too. Among valence characteristics, voters place a good deal of importance on the amount of information provided about each candidate's sources of funding. Figure 1 presents responses from the 2015 CCES to a question about the importance of various valence characteristics. Of the 2000 respondents, $710(35.5 \%)$ rated campaign finance disclosure as equal to or more important than all other items ranked. The responses also suggest that as a valence characteristic, campaign finance transparency is less important than valence attributes that are central to governing (persuasiveness, grasp of the issues) and more important than campaign-related valence attributes (money raised, support from small donors).

It would not require a strong preference for transparency or a strong distaste for scandal to observe voters preferring more transparent candidates. Disclosure information lends credibility to (or undermines) candidate claims about policies because it reveals whether the donor's interests and candidate's stated policy preferences match (Gilbert, 2013; Oklobdzija, 2019). A dislike for uncertainty along the policy dimension alone could lead voters to abandon candidates who receive dark money support. If dark money groups support a candidate, voters cannot see all the interests and groups to whom the candidate may be responsive on policy matters once in office, thus increasing uncertainty and undermining credibility. 
On the other hand, scholars tend to think that voters prioritize candidates' policy positions over candidates' non-policy (valence) traits (Page \& Jones, 1979; Franchino \& Zucchini, 2015). But campaign finance transparency and policy have not been tested together. These competing theories lead to competing hypotheses about the interaction between voter-candidate policy distance and the voter's evaluation of candidate campaign finance transparency. Either voters want to "know what they're getting" in the policy realm, and obscuring campaign finances adds uncertainty:

H3a Uncertainty hypothesis: The magnitude of effects in $\mathrm{H} 1$ and $\mathrm{H} 2$ will not decrease as the policy distance between the voter and candidate increases.

Or policy preferences will trump candidate campaign finance transparency:

H3b Policy trumps transparency hypothesis: The magnitude of effects in $\mathrm{H} 1$ and $\mathrm{H} 2$ will decrease as the policy distance between the voter and candidate increases.

Finally, the voter's partisan affiliation and ideology may matter independently of ideological or policy distance from candidates in a way that helps us better understand the conditions under which transparency should be considered a valence characteristic. Scholars have argued that liberal voters are most likely to support and demand transparency (Piotrowski \& Van Ryzin, 2007), a sentiment echoed by the news media. Elite political rhetoric can also divide voter reaction, providing "cues" for how voters should feel about campaign finance transparency (Lupia \& McCubbins, 1998; Zaller, 1992). Campaign finance transparency is a site of elite partisan disagreement. Senate minority leader Mitch McConnell (R-KY) has long opposed most campaign finance regulations, including disclosure, and Democrats in the House of Representatives recently passed a bill that would fill gaps in the disclosure regime. ${ }^{2}$ If prior scholars are correct, or if voters are "getting the message" from party leaders, then Republicans should be less responsive to variations in candidate campaign finance transparency and compliance than Democrats. However, party members hold a range of ideologies. Ideological extremists may treat transparency or complianceasapartisan issue, with extreme liberals reacting differently from extreme conservatives. By contrast, ideological moderates may view these as valence issues, reacting similarly to the information across moderate ideologies. This leads to my final hypothesis: ${ }^{3}$

H4a Party signaling hypothesis: Transparency and compliance-related rewards [punishments] will be larger among Democrats than among Republicans.

\footnotetext{
${ }^{2}$ For the People Act of 2021, H.R. 1, 117th Cong. (2021).

3 Respondents are not randomized into preferences. Subgroup analysis based on distance is built from those preferences. Findings from $\mathrm{H} 3$ and $\mathrm{H} 4$ should be conservatively understood as associational, not causal.
} 
H4b Mixed reaction hypothesis: Ideological extremists will react differently from each other to transparency and compliance information (a partisan issue), whereas ideological moderates will react similarly to each other (a valence issue).

$\mathrm{H} 1 \mathrm{a}, \mathrm{H} 2 \mathrm{~b}, \mathrm{H} 4 \mathrm{a}$, and H4b are tested in both experiments. H1b, H2a, H3, and H3b are tested in Study 2.

\section{Experimental Designs and Results}

The hypotheses are tested in two survey experiments conducted using nationally representative samples. Study 1 was part of the 2015 CCES. Study 2 was run using Bovitz Inc.'s panel in spring 2019. ${ }^{4}$ Panel demographics, with comparison to the American Community Survey, are available in Appendix 2. While the samples are similar to the general population, there are some differences. Survey respondents were younger and whiter than the general population. Both samples had more respondents with incomes under $\$ 50,000$ than the general population and fewer people with incomes over $\$ 200,000$.

The setting for both studies is a primary for an open seat in the respondent's state senate.

\section{Study 1: Design}

Candidates Julia Johnson and Pearl Conley are described as competing for an open seat in the state Senate. ${ }^{5}$ The candidates receive a policy evaluation from a "local political scientist," in which they are rated 1-100 on how liberal or conservative they are. ${ }^{6}$ Respondent's state and party are populated based on earlier questions, with true independents randomized into a party. Candidate Johnson's ideology mirrors the respondent's ideology, as previously self-identified on a 1-10 scale. Conley is 20 percentage points more extreme, unless the respondent self-identifies as a 9 or 10 , in which case Conley is said to be 20 points more moderate. Results are robust to excluding these cases (Appendix 4A). ${ }^{7}$ Figure 2 contains a sample vignette; the complete vignette and all question wording are available in Appendix 3.

\footnotetext{
${ }^{4}$ Bovitz, Inc., is an opt-in internet panel vendor with respondents recruited through random digit dialing and empanelment of Americans with Internet access. Samples were drawn to match the U.S. voting-aged population. Because the research question ultimately lies in comparisons across experimental conditions, the use of a non-probability sample is not problematic (Druckman \& Kam, 2011). However, respondents in samples like these tend to have higher political interest than the average American (Malhotra \& Krosnick, 2007), a tendency that biases these results toward zero.

5 Nebraskans saw "Legislature.".

6 See Tomz and Van Houweling (2008) and Rogowski and Sutherland (2016) for other examples of ideology on a numeric scale.

${ }^{7}$ Results are substantively and statistically similar in a replication where candidates' ideology difference is 10 points, though Conley's favorability change loses statistical significance (Appendix 4B).
} 


\begin{abstract}
Julia Johnson and Pearl Conley are competing in the Republican primary for an open seat in the state senate. A local political scientist working for the Republican party has evaluated the candidates on their policies, with 1 being not at all conservative and 100 being very conservative.

The political scientist scored Johnson a 20 and Conley a 40.

A group of nonpartisan transparency advocates rates candidates based on how much of their campaign finance information is disclosed to the public. They call their ratings "transparency grades". A grade of " $A$ " means high transparency, and a grade of " $F$ " means no transparency.

Johnson received a transparency grade of " $C$ " and Conley received a transparency grade of " $\mathrm{A}$ ". Johnson received a low grade because her campaign has received support from independent groups that allow their donors to remain anonymous. Conley received a high grade because both she and the independent groups supporting her candidacy disclose more campaign finance information than the law requires.
\end{abstract}

Fig. 2 Example vignette, Study 1, for Republican in treatment group with "conservativism" of 2 out of 10

Each of 504 respondents was randomly assigned to one of two experimental conditions: a control group that only saw the policy scores, and a treatment group that saw the policy scores as well as the transparency grades from a "group of nonpartisan transparency advocates." Johnson always receives a "C" for transparency, and Conley always receives an "A." Johnson's "low grade" is because her "campaign has received support from independent groups that allow their donors to remain anonymous." (The phrase "dark money" is not in the vignette.) Conley's "high grade" is "because both she and the independent groups supporting her candidacy disclose more campaign finance information than the law requires." ${ }^{\circ}$ After reading the vignette, respondents answered a series of questions on favorability and vote choice (Gerber et al., 2013; Wright et al., 2016).

Table 2 summarizes the treatment conditions in Study 1.

\title{
Study 1: Results
}

Figure 3 displays the main results of Study 1. Respondents did not differentiate between the candidates based on policy, so instead we focus analysis on respondents' reactions to positive and negative information about dark money (H1a, H2b, and H4). ${ }^{9}$ Analysis of $\mathrm{H} 3$ is in Study 2.

H1a predicts that respondents will punish a lack of transparency, even when the lack of transparency does not violate the law, and even when it is not the candidate's fault, as is the case with Johnson's dark money support. Respondents told that

\footnotetext{
${ }^{8}$ Disclosure grades are common. See, e.g., transparency and disclosure grades at https://ballotpedia.org/ Transparency_checklist; https://www.followthemoney.org/research/institute-reports/scorecard-essentialdisclosure-requirements-for-contributions-to-state-campaigns-2016, and https://campaigndisc.calvoter. org.

${ }^{9}$ The control group was equally favorable between Johnson and Conley (55.3) and was slightly more likely to vote for Conley (58.4) over Johnson (54.8, difference not statistically significant).
} 


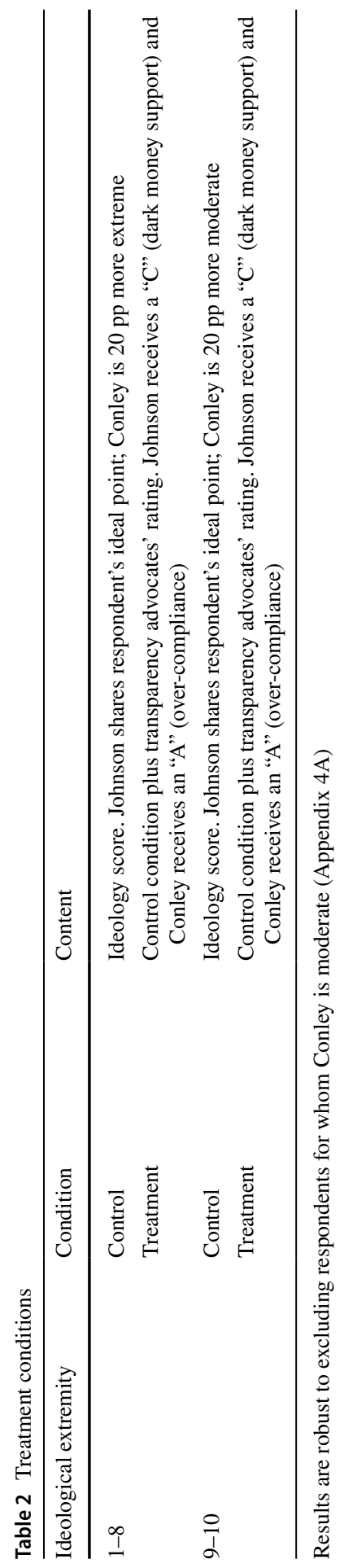




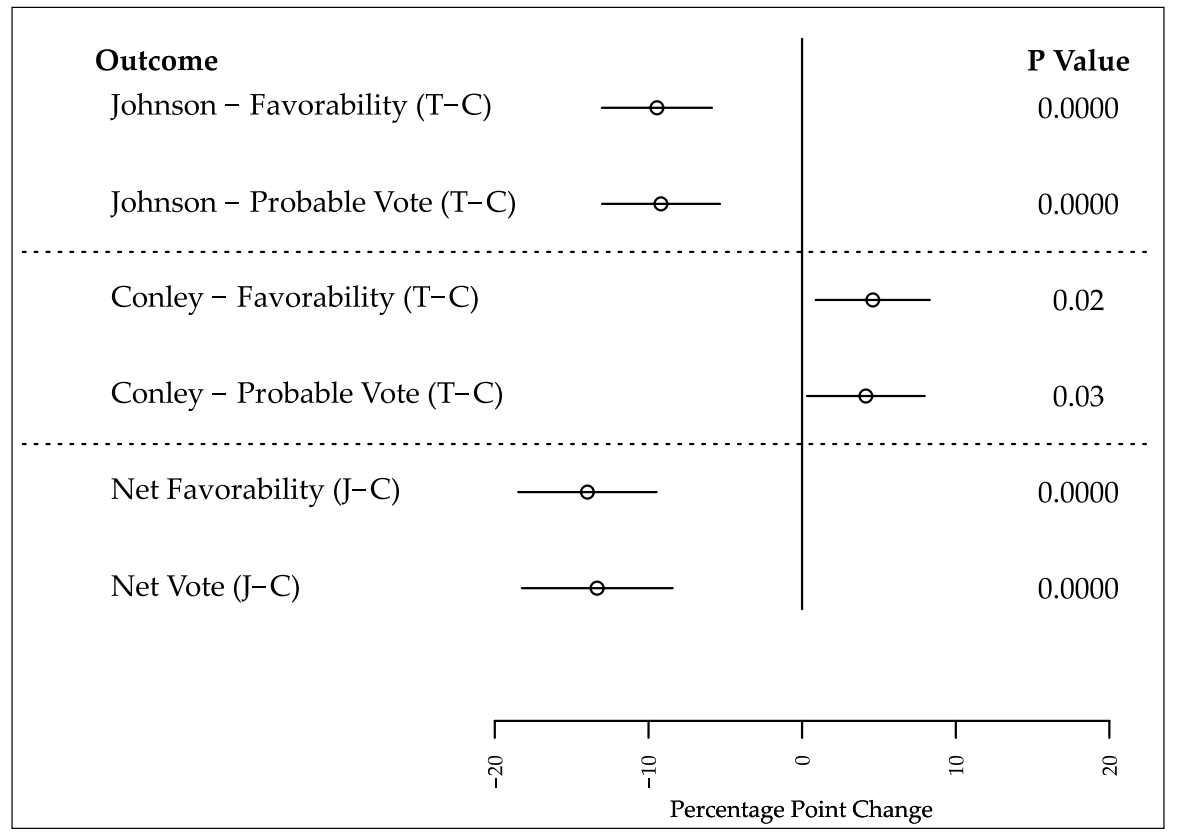

Fig. 3 Differences in 504 respondents' mean favorability and probable vote choice among the treatment group, minus the mean favorability and probable vote choice among the control group, for Johnson (dark money support, top rows) and Conley (over-complies, middle rows). Net effect in the bottom rows. The open circles show the difference in means, lines show a 95\% confidence interval, 2-sided p-values on right

Johnson has dark money support disapproved (45.9 and 45.6 on favorability and vote choice). The resulting favorability gap is $-9.45(95 \% \mathrm{CI}=[-13.03,-5.90])$; vote choice gap is $-9.19[-13.03,-5.35]$.

$\mathrm{H} 2 \mathrm{~b}$ predicts that respondents will reward over-compliance with campaign finance laws. The middle rows in Fig. 3 show Conley's reward for over-compliance. Respondents in the treatment group rated Conley 59.9, for favorability a difference of $4.6[0.88,8.32]$ from the control group. Vote choice results are similar, at 4.15 $[0.32,7.99]$. The differences are statistically and substantively significant; respondents rewarded transparency, though not as much as they punished lack of transparency. The bottom two rows of Fig. 3 show the net effects and combine the favorability and vote choice losses to Johnson with the favorability and vote choice gains to Conley. Net favorability is estimated to be -13.99 [ $-18.47,-9.47]$, and net vote likelihood - 13.3 [- 18.24, - 8.43].

In the vignette, Conley and her supporting groups are not only complying with disclosure laws, they are over complying with disclosure laws. ${ }^{10}$ In order to keep

\footnotetext{
${ }^{10}$ Respondents might not be rewarding transparency per se; they might be rewarding over-compliance with the law. Respondents' answers explaining their choice often mentioned transparency. None mentioned over-compliance. Study 2 helps to adjudicate between these two mechanisms.
} 
treatment and control vignettes similar in length, the type of over-compliance by Conley and supporting groups was left vague in the treatment vignette. However, some kinds of over-compliance are more useful than others. Study 2 explores these questions.

\section{Study 1 Exploratory Analysis: Liberals vs. Conservatives, or Extremists vs. Moderates?}

H4 predicts differences based on partisanship and ideology. H4a predicts that Democrats will have larger effect sizes than Republicans. The results were mixed. Republicans were more punitive toward Johnson for favorability (F-statistic 5.26, $\mathrm{p}=0.02$ ), and Democratic respondents may be more likely to vote for Conley $(\mathrm{F}$-statistic $=2.18, \mathrm{p}=0.14)$; other differences were not statistically significant (Appendix 5A).

$\mathrm{H} 4 \mathrm{~b}$ raises the possibility that extremists will react differently from each other, whereas moderates will react similarly. To examine that possibility, Fig. 4 presents outcomes by respondents' political ideology, with Johnson in the left column and Conley in the right. The arrows are drawn from the mean response in the control group to the mean response in the treatment group. Ideologically extreme respondents in the control group gave higher evaluations to Johnson than their more moderate counterparts. The pattern in Fig. 4 suggests that the extreme respondents were most punitive, regardless of ideology. While we lose statistical power by dividing the data into 7 smaller groups of respondents, the differences are statistically distinguishable from zero for respondents who describe themselves as "very liberal," "somewhat liberal," "somewhat conservative" and "very conservative" (Appendix 5C).

When it comes to rewarding Conley, extremists reacted more similarly to each other than to their co-partisans. They did not reward Conley for her transparency. Only respondents who describe themselves as "middle of the road" have treatment-control differences that are statistically distinguishable from zero (10.58 [3.23, 17.94] for favorability and 10.29 [3.19, 17.38] for vote choice) (Appendix 5C). Political knowledge and interest correlate with ideological extremity, and these results are robust to controlling for both variables (Appendix 5D).

Dividing the data into extremists (ideology 1 and 7) and more moderate respondents (everyone else) buys statistical power. Randomization inference indicates that extremists did react differently than moderates in all but the Johnson vote choice (Appendix 5B).

The results of Study 1 suggest that, on average, respondents were willing to reward over-disclosure and punish a lack of transparency, even where it is perfectly legal. The results also suggest that the punishment effect is largely driven by extreme conservatives and extreme liberals, who behave similarly and seem largely immune to the differences in the rhetoric of their political elites. Conversely, the rewards to Conley are driven by more moderate voters.

Recall that the control group did not react to the ideological differences between the candidates. After Study 1, we are still left with the question of how much policy 

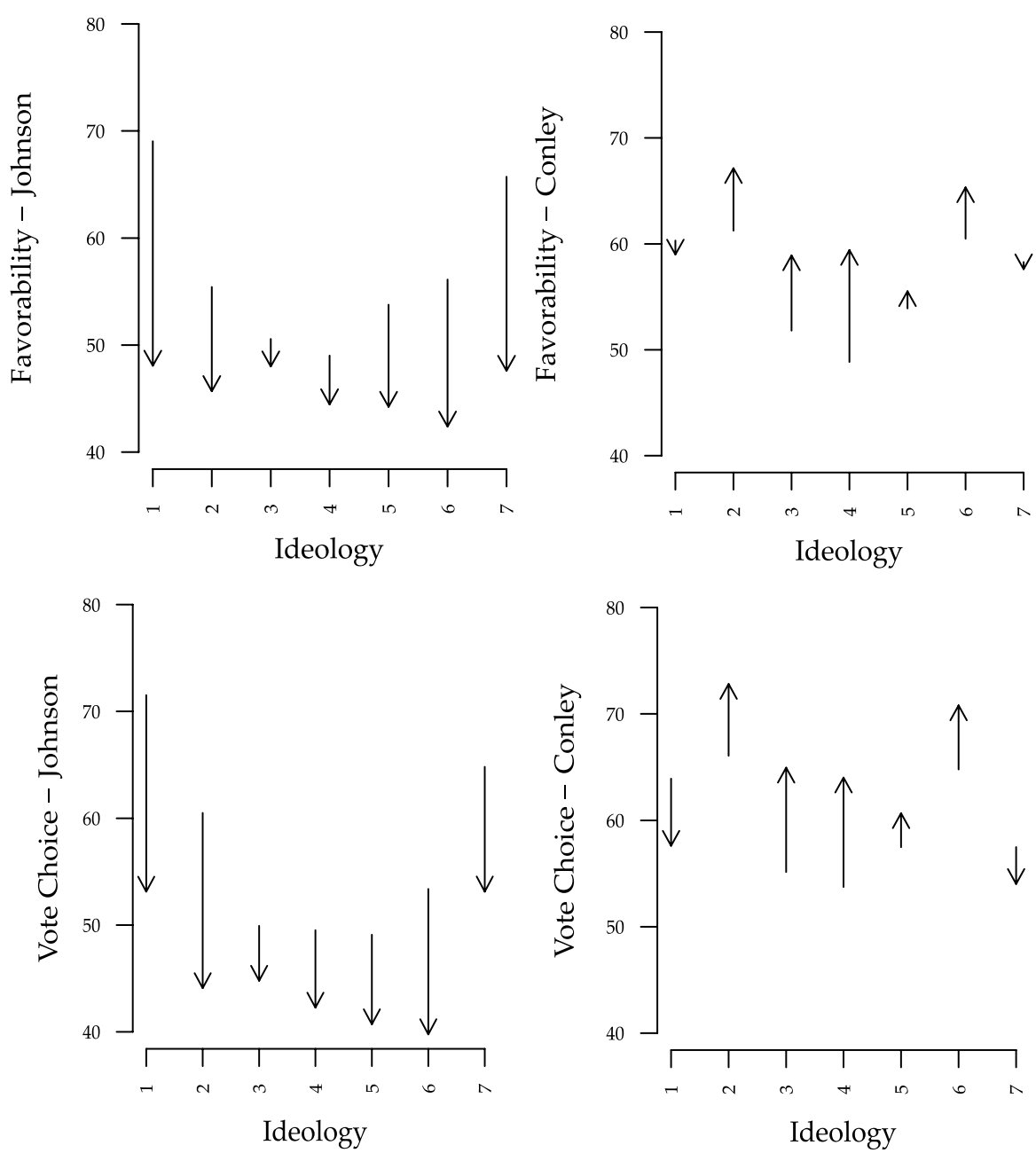

Fig. 4 Average treatment and control group evaluations on favorability (top) and vote choice (bottom) for Johnson (left, ideologically similar to respondent, less transparent) and Conley (right, ideologically more distant from respondent, more transparent). Responses shown by ideology, from very liberal (1) to very conservative (7), with 4 being "middle of the road." Control (treatment) group evaluations are presented as the tail (head) of the arrows. Appendix 5C contains estimates and 95\% confidence intervals

mismatches can affect voter preferences for more transparency. Study 2 forces the issue by placing respondents in a context that includes policy stances and other valence attributes along with compliance and transparency. 


\section{Study 2: Design}

For Study 2, 1490 voting age respondents answered questions about their policy preferences and ideologies. ${ }^{11}$ They returned 7-14 days later to evaluate six pairings of candidate profiles, choosing one candidate from each pairing and evaluating each candidate's trustworthiness on a five-point scale. The study is a choice-based conjoint analysis, which requires respondents to confront complete candidate profiles that vary across multiple attributes. Conjoint analysis allows researchers to estimate how much a given candidate attribute (here, policy position, transparency, compliance, and valence attributes) increases or decreases the chance that a given profile is selected, a quantity called the Average Marginal Component Effect, or AMCE (Hainmueller et al., 2014; Horiuchi et al., 2018; Mummolo \& Nall, 2017; Sen, 2017).

The context is again a primary election for an open seat in the state senate, and respondents are again assigned to a party based on their party identification and ideology expressed in wave 1 , with true independents again randomized into a party primary. ${ }^{12}$ The complete set of attributes is in Table 3 .

For campaign finance transparency, respondents view levels of an attribute that does not involve compliance with campaign finance law (testing H1a, H2a) and one about compliance specifically (testing $\mathrm{H} 1 \mathrm{~b}, \mathrm{H} 2 \mathrm{~b}$ ). The transparency attribute that does not also implicate compliance concerns dark money, which is legal, if unpopular. The three dark-money-related levels, from strongest to weakest transparency stance, are (1) discouraged dark money support; (2) supported by dark money groups; and (3) raised dark money before declaring their candidacy. Raising money for an eventual dark-money group before declaring is legal, if not transparent. The phrase "dark money" is not used in the instrument; instead, respondents read about "groups with anonymous donors."

The compliance-related attribute levels relate to campaign finance law and are as follows: (1) out of compliance due to missed filing deadlines; (2) out of compliance due to missing contributions; (3) in compliance (reference category); (4) in compliance with number of small donors on the campaign's website; and (5) in compliance with a zip-code level map of donors on the website. ${ }^{13}$ The conjoint also includes common valence traits: total amount raised, percent of funding from small donors, professional background, persuasiveness in public, and grasp of the issues (Adams et al., 2011; Kirkland \& Coppock, 2017; Spencer \& Theodoridis, 2020). Persuasiveness and grasp of issues are presented as "media evaluations" of the candidate.

\footnotetext{
11 Survey instruments and pre-analysis plan for Study 2 are in Appendix 3.

12 Appendix 3C explains wave 1. Results are robust to excluding independents (Appendix 6).

13 Levels were provided to analyze whether respondents adjudicate between violations potentially related to honesty or corruption (missing contributions) or potentially indicating disorganization or management problems (missed deadlines), and whether they discriminate between over-compliance that is more (map) or less (number of small donors) informative. Respondents treated these levels of over and under compliance as equivalent, so I pool them for most of the analysis. The use of the word "compliance" in the conjoint may have raised the salience of the regulatory regime for respondents.
} 
Table 3 Conjoint attributes and levels, Study 2

Suppose you were voting in a [PARTY] primary for an open seat for state senate in your state. Please view the following two candidate profiles and answer the questions below.

\begin{tabular}{|c|c|c|c|}
\hline & Candidate A & Candidate B & Values \\
\hline $\begin{array}{l}\text { Position on policy prohibiting } \\
\text { state police officers from } \\
\text { inquiring into immigration } \\
\text { status of people they encounter }\end{array}$ & value & value & $\begin{array}{l}\text { strongly supports } \\
\text { supports } \\
\text { opposes } \\
\text { strongly opposes }\end{array}$ \\
\hline $\begin{array}{l}\text { Position on policy requiring } \\
\text { public schools to offer } \\
\text { comprehensive sex education }\end{array}$ & value & value & $\begin{array}{l}\text { strongly supports } \\
\text { supports } \\
\text { opposes } \\
\text { strongly opposes }\end{array}$ \\
\hline $\begin{array}{l}\text { Compliance with } \\
\text { campaign finance rules }\end{array}$ & value & value & $\begin{array}{c}\text { Out of compliance } \\
\text { (has missed filing deadlines) } \\
\text { Out of compliance } \\
\text { (has not reported some contributions) } \\
\text { In compliance } \\
\text { In compliance, and website gives extra } \\
\text { information (number of small donors) } \\
\text { In compliance, and website gives extra } \\
\text { information (map with number of donors } \\
\text { from each zip code) }\end{array}$ \\
\hline $\begin{array}{l}\text { Relationship to groups } \\
\text { with anonymous donors }\end{array}$ & value & value & $\begin{array}{l}\text { Requested that groups with anonymous } \\
\text { donors not support candidacy. } \\
\text { Supported by groups with } \\
\text { anonymous donors. } \\
\text { Prior to announcing candidacy, raised } \\
\text { money for a group with anonymous donors } \\
\text { that now supports campaign }\end{array}$ \\
\hline Total amount raised & value & value & $\begin{array}{c}\$ 250,000 \\
\$ 500,000 \\
\$ 1,000,000\end{array}$ \\
\hline $\begin{array}{l}\text { Small donor support } \\
\text { (as \% of total amount } \\
\text { raised) }\end{array}$ & value & value & $\begin{array}{l}40 \% \\
60 \% \\
80 \% \\
\end{array}$ \\
\hline Professional background & value & value & $\begin{array}{c}\text { Student } \\
\text { Small Business Owner } \\
\text { School Principal } \\
\text { Mayor } \\
\text { Head of state agency }\end{array}$ \\
\hline $\begin{array}{l}\text { Media evaluation of candidate's } \\
\text { ability to be persuasive in public }\end{array}$ & value & value & $\begin{array}{l}\text { Extremely persuasive } \\
\text { Somewhat persuasive } \\
\text { Not very persuasive }\end{array}$ \\
\hline $\begin{array}{l}\text { Media evaluation of candidate's } \\
\text { Grasp of the issues }\end{array}$ & value & value & $\begin{array}{c}\text { Excellent } \\
\text { Decent } \\
\text { Weak }\end{array}$ \\
\hline
\end{tabular}

Respondents also view attributes for policies that were determined after wave 1 to be important (immigration) or not very important (comprehensive sex ed) to most respondents. Respondents reported their degree of agreement or disagreement with the specific policies during wave 1. They were asked whether they "strongly support," "support," "oppose," or "strongly oppose" policies prohibiting state police from inquiring about immigration status and requiring comprehensive sexual 
Table 4 Formalizing hypotheses for Study 2

\begin{tabular}{|c|c|}
\hline Hypothesis & Study 2 expectation, where $\mathrm{Y}=\mathrm{AMCE}$ \\
\hline $\begin{array}{l}\text { H1a: Respondents will punish candidate relationships } \\
\text { with dark money }\end{array}$ & $\begin{array}{l}{[\mathrm{Y} \mid \text { raised dark money }]<} \\
{[\mathrm{Y} \mid \text { dark money support }]<[\mathrm{Y} \mid \text { discouraged dark }} \\
\text { money }]\end{array}$ \\
\hline H1b: Respondents will punish noncompliance & $\begin{array}{l}{[\mathrm{Y} \mid \text { reporting gaps }] \leq} \\
{[\mathrm{Y} \mid \text { missed deadlines }]<} \\
{[\mathrm{Y} \mid \text { in compliance }]}\end{array}$ \\
\hline $\begin{array}{l}\text { H2a: Respondents will reward candidates who do not } \\
\text { have/discourage dark money support }\end{array}$ & $\begin{array}{l}{[\mathrm{Y} \mid \text { raised dark money }]>} \\
{[\mathrm{Y} \mid \text { dark money support }]>[\mathrm{Y} \mid \text { discouraged dark }} \\
\text { money }]\end{array}$ \\
\hline H2b: Respondents will reward over-compliance & $\begin{array}{l}{[\mathrm{Y} \mid \text { map on site }] \geq} \\
{[\mathrm{Y} \mid \text { donors on site }]>} \\
{[\mathrm{Y} \mid \text { in compliance }]}\end{array}$ \\
\hline H3a: Uncertainty hypothesis & $\begin{array}{l}\text { Where } d \text { is the distance between R's preferred } \\
\text { policy and the candidate's policy, } \\
{[\mathrm{Y} \mid d=0] \cong[\mathrm{Y} \mid d=1] \cong[\mathrm{Y} \mid d=2] \cong[\mathrm{Y} \mid d=3]}\end{array}$ \\
\hline H3b: Policy trumps valence & {$[\mathrm{Y} \mid d=0] \geq[\mathrm{Y} \mid d=1] \geq[\mathrm{Y} \mid d=2] \geq[\mathrm{Y} \mid d=3]$} \\
\hline H4a: Party signaling hypothesis & For predictions in $\mathrm{H} 1-\mathrm{H} 2,\left|Y_{\text {Dem }}\right|>\left|Y_{\text {Rep }}\right|$ \\
\hline H4b: Mixed reaction hypothesis & $\begin{array}{l}\text { For predictions in } \mathrm{H} 1-\mathrm{H} 2 \\
\left|Y_{\text {ext.lib }}\right| \neq \mid Y_{\text {ext.cons } \mid} \\
\left|Y_{\text {mod.lib }}\right| \cong \mid Y_{\text {mod.cons } \mid}\end{array}$ \\
\hline
\end{tabular}

education in the state's public schools. Only one attribute level constraint was used: no candidate in the Democratic primary could strongly oppose these policies, and no candidate in the Republican primary could strongly support them. ${ }^{14}$ Respondents' reactions to transparency information in the presence of policy (dis)agreement with the candidates allows me to evaluate $\mathrm{H} 3 \mathrm{a}$ and $\mathrm{H} 3 \mathrm{~b}$.

Each respondent saw six contests, or pairs of profiles. Within respondent, all questions were randomly ordered within randomly ordered blocks (policy, campaign finance transparency, and other valence attributes). Respondents' candidate choices (1/0 for each candidate for each pair) allow me to estimate the AMCE using least squares regression. Attribute levels enter as categorical variables. The coefficient on each level is a measure of the marginal effect of that level relative to the omitted level and controlling for the other traits. Standard errors are clustered by respondent.

Table 4 presents hypotheses again, this time with expectations specific to Study 2.

\footnotetext{
14 The probability that one attribute level (strongly support or strongly oppose) is chosen is 0 for candidate profiles from each party (Republicans or Democrats) and uniform otherwise. I account for this by creating a "constraints" type design in the cjoint() package in R (Barari et al.). The constraints also create dependencies in the data, requiring cluster-robust standard errors (Hainmueller et al., 2014). See Appendix 3B.
} 


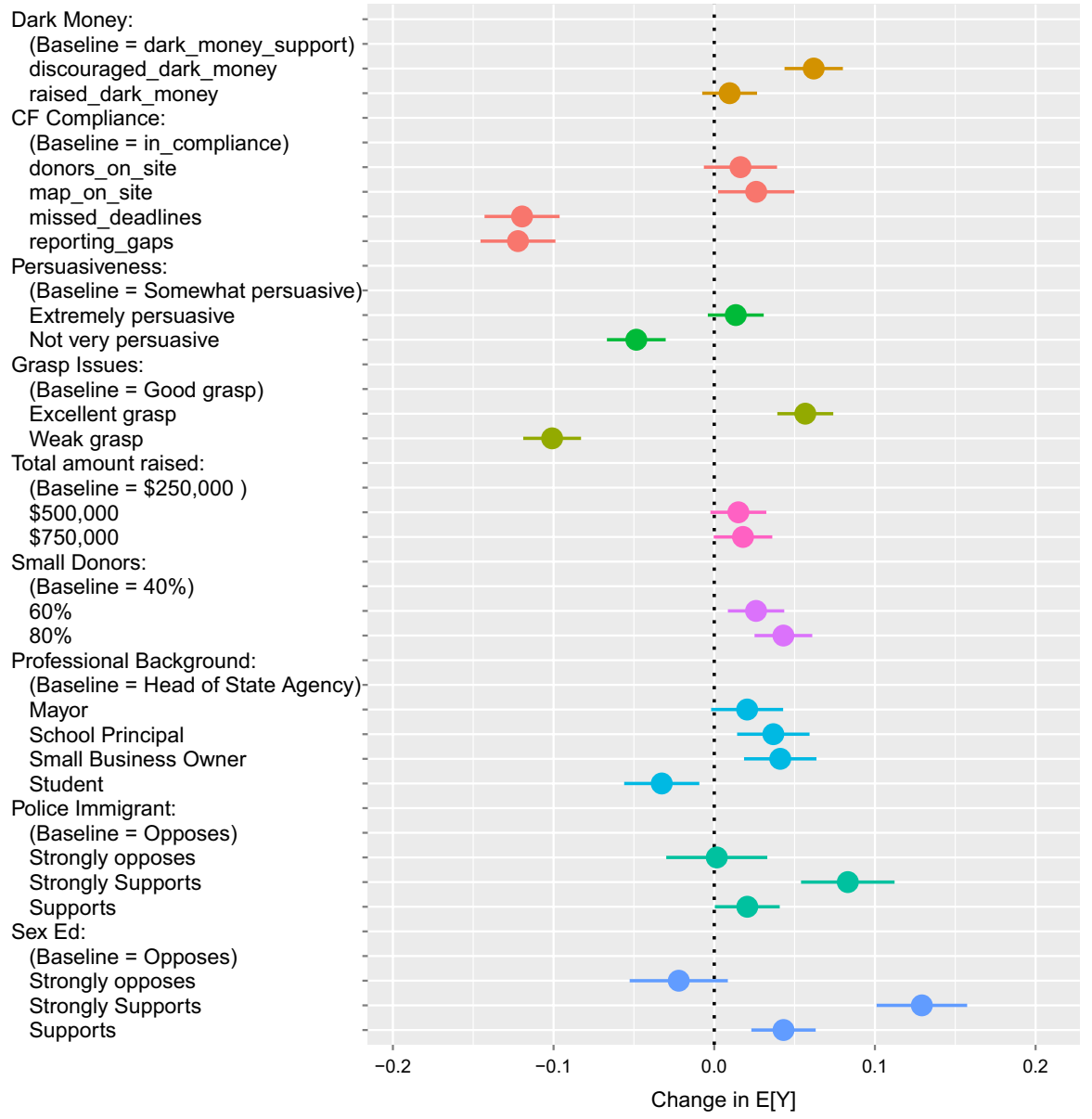

Fig. 5 Overall results from conjoint analysis in which 1490 respondents viewed 8931 candidate contests. Movement along horizontal axis indicates increase (decrease) in probability that respondent selected a candidate with that trait, the Average Marginal Component Effect (closed circles). Lines show 95\% confidence interval

\section{Study 2: Results}

Figure 5 presents the overall results for Study $2 .^{15}$

H1a predicts respondents will punish lack of transparency that does not implicate compliance problems. The AMCE for raised dark money (AMCE $=0.0195 \%$ $\mathrm{CI}=[-0.01,0.03])$ is indistinguishable from supported by dark money, the baseline level. However, respondents may have interpreted the baseline category, supported by dark money, as similarly non-transparent to raised dark money, such that

15 Results are stable with no carryover effects: only 5 of 138 interactions with contest number were significantly different from the first contest using $\alpha=0.05$, a result we would expect to occur at random. There are also no profile order effects. 


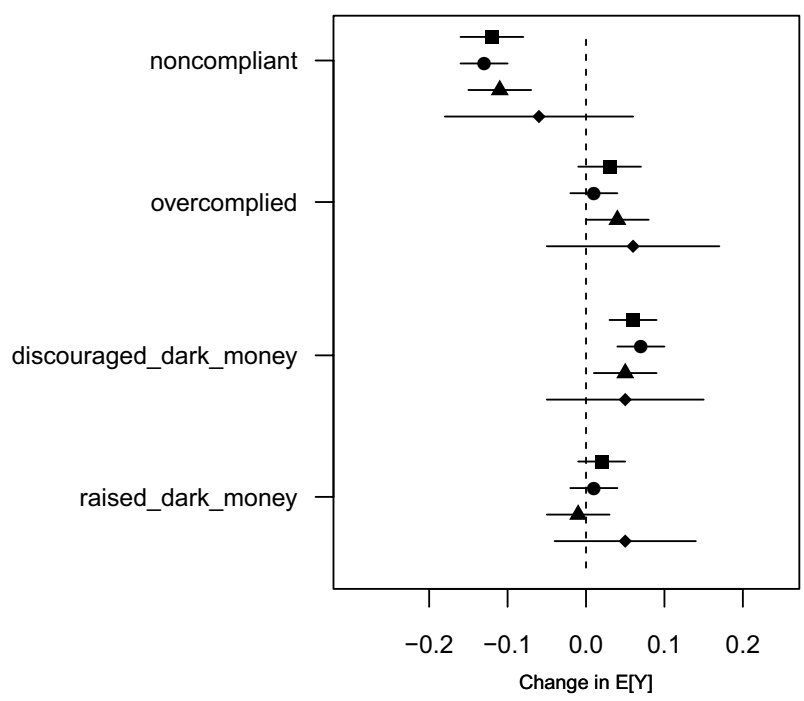

Fig. 6 AMCEs by policy distance among profiles where respondent-candidate policy distance is 0 (square, immigration $\mathrm{N}=5318$, sex ed $\mathrm{N}=5351$ ), 1 (circle, $\mathrm{N}=7825,7869$ ), 2 (triangle, $\mathrm{N}=4114$, 3937 ), and 3 (diamond, $N=605,705$ ). A square, or a distance of 0 , means respondent and candidate policy preferences match, and a diamond, or distance of 3, means the respondent's position was "Strongly Supports" or "Strongly Opposes" and the candidate's position was the opposite. Policies are immigration (left) and sex ed (right). Baseline compliance level is "in compliance." Baseline dark money level is "receives support from groups who do not disclose their donors."

both are "punished" equally. (Recall dark money support earned Johnson her "C" in Study 1.) Future research is needed to parse these differences. H1b predicts that respondents will punish candidate disclosure compliance problems. Respondents are 12 percentage points less likely to choose a candidate who missed deadlines $(-0.12$, $[-0.14,-0.10])$ or had missing contributions $(-0.12,[-0.14,-0.10])$.

$\mathrm{H} 2 \mathrm{a}$, predicting respondents will reward a commitment to transparency that does not implicate compliance, is supported. Discouraged dark money is positive and statistically distinguishable from the baseline of supported by dark money $(0.062$, $[0.04,0.08]) . \mathrm{H} 2 \mathrm{~b}$, that respondents will reward candidate over-disclosure, is marginally supported in the overall results, with the website map $(0.026,[0.002,0.05])$ distinguishable from "merely" being in compliance (baseline level), but website information about small donors not distinguishable $(0.02,[-0.01,0.04])$. When pooled, the AMCE for over-compliance is distinguishable from $0(0.02,[0.001$, $0.04])$.

$\mathrm{H} 3 \mathrm{a}$ predicts that as policy distance increases between the voter and candidate, the rewards to campaign finance transparency (punishment for lack of transparency) will be fairly stable, and $\mathrm{H} 3 \mathrm{~b}$ predicts that rewards and punishments will decrease in absolute value as policy preference distance between the candidate and respondent increases. Figure 6 presents results based on policy agreement. Policy preference distance is measured as the distance between the respondent's support for the policy and the candidate's support for it, reflecting a perfect match (0), or 1 , 2 , or 3 degrees of agreement apart. Because of the construction of the experiment 


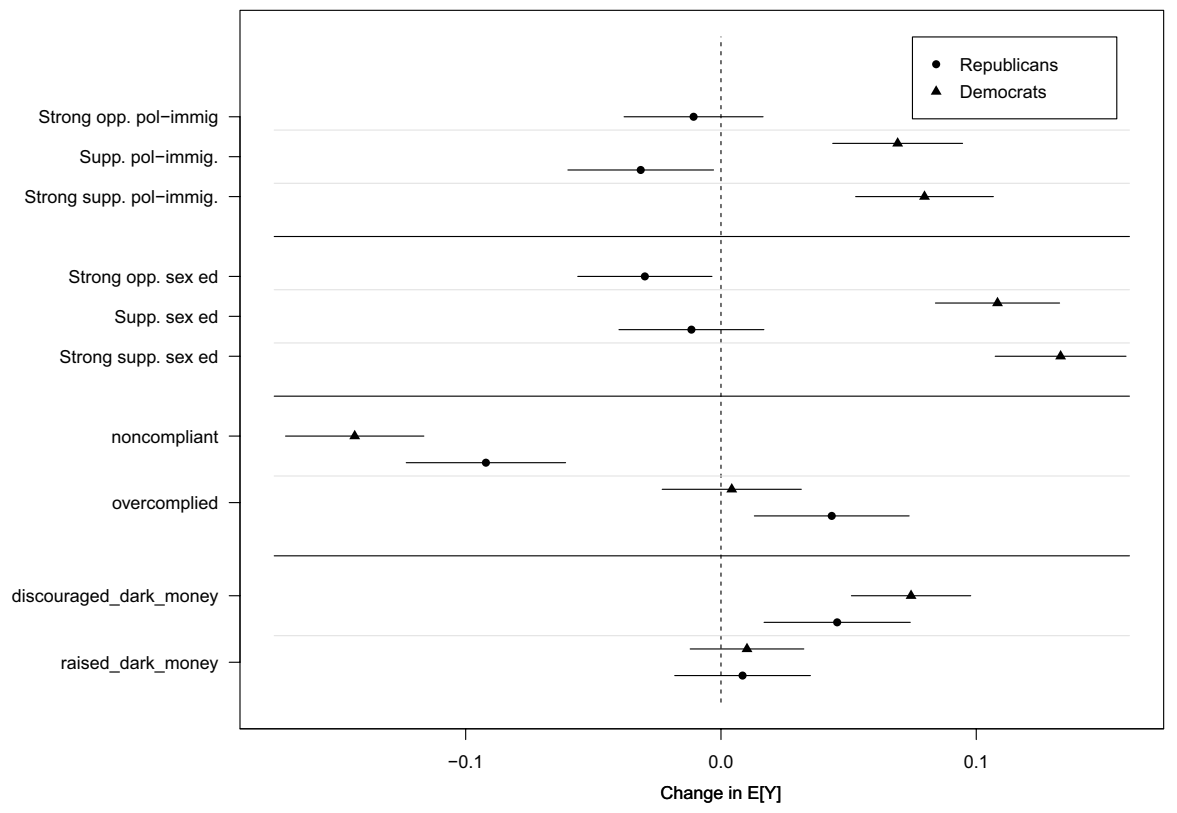

Fig. 7 AMCE estimates for Democratic respondents (triangles, $\mathrm{N}=10,088$; 841 respondents) and Republicans respondents (circles, $\mathrm{N}=7774 ; 649$ respondents). Only Republicans saw candidates strongly oppose the policies, and only Democrats saw candidates strongly support them. Baseline compliance level is "in compliance." Baseline dark money level is "receives support from groups who do not disclose their donors."

and randomization constraints on the attributes of candidates running in each party's primary, only $3.3 \%$ of profiles were presented to respondents who said they strongly opposed [strongly supported] a policy and featured candidates that strongly supported [strongly opposed] it.

If $\mathrm{H} 3 \mathrm{~b}$ were supported, respondents viewing big policy mismatches (triangles and diamonds) would react less to transparency, compared to respondents viewing good policy matches. Aside from the rare respondents for whom the candidate's policy support was 3 degrees from the respondents' position, the estimates are rather stable, supporting H3a. For example, respondents ranged between $-0.10[-0.13,-0.07]$ and $-0.14[-0.18,-0.10]$ in their AMCEs on noncompliance. Their reward to candidates who discouraged dark money was also fairly stable, ranging between $0.04[0.00,0.08]$ and $0.07[0.04,0.10]$. The same is true for other non-policy traits, such as grasp of issues, funding from small donors, and total amount raised (Appendix 7). There is also little difference in the transparency-related estimates across important (immigration) and less important (sex ed) policy areas, rather than transparency being more influential where the policy area is perceived as less important.

$\mathrm{H} 4 \mathrm{a}$ predicts that effects will be larger among Democrats than Republicans. Figure 7 shows the effects for Republicans (circles) and Democrats (triangles), testing $\mathrm{H} 4 \mathrm{a}$. As is clear in the Figure, estimated AMCE for punishing noncompliance differs across parties in the predicted direction: Republicans' AMCE is 


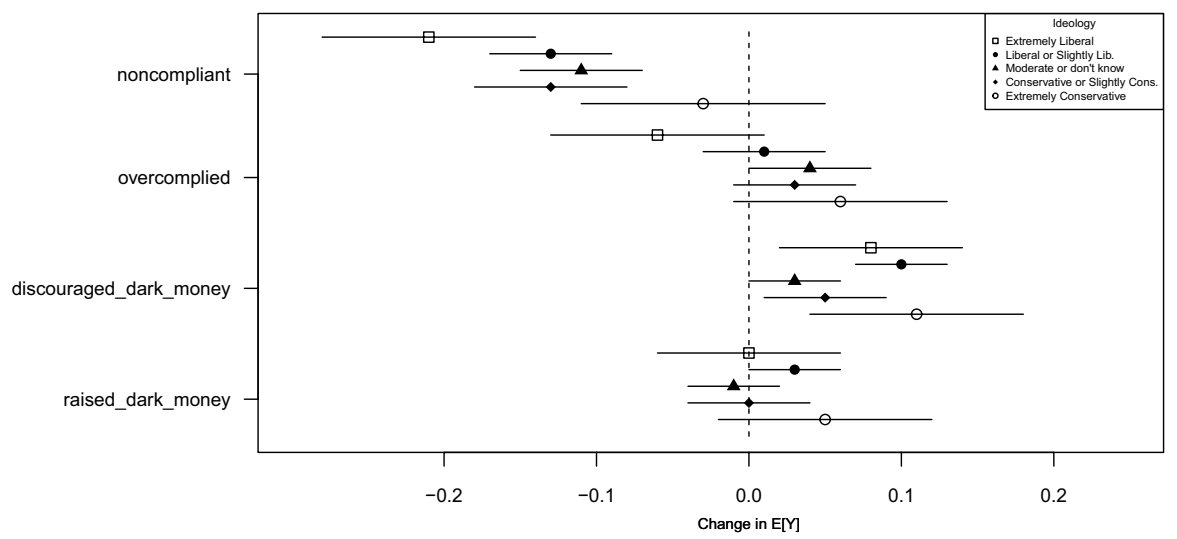

Fig. 8 AMCEs of varying levels of transparency among people who describe themselves as Extremely Liberal (open square, $\mathrm{N}=1312 ; 110$ respondents), Liberal or Slightly Liberal (black circle, $\mathrm{N}=4968$; 414 respondents), Moderate or Haven't Thought about It (triangle, $\mathrm{N}=6284 ; 523$ respondents), Conservative or Slightly Conservative (diamond, $\mathrm{N}=4102 ; 343$ respondents), Extremely Conservative (open circle, $\mathrm{N}=1196$; 100 respondents). Compliance baseline is "in compliance." Dark money baseline is "receives support from groups who do not disclose their donors." Estimates and confidence intervals in Appendix 9A

- $0.09[-0.12,-0.06]$ and Democrats' is $-0.14[-0.17,-0.11]$. The difference in marginal means is not statistically significant for noncompliance but is for the baseline category of "mere" compliance (Appendix 8) (Leeper et al., 2020). Democrats are more rewarding of a candidate distancing herself from dark money $(0.07$ [0.05, 0.09]), but Republicans do still reward that behavior $(0.05$ [0.02, 0.08]; R-D marginal means difference - 0.02 [- 0.05, 0.00]). As Appendices $8 \mathrm{~A}$ and $8 \mathrm{~B}$ show, we also observe relative stability of responses across parties for persuasiveness in public, grasp of the issues, and other campaign valence traits. These small differences between partisans for campaign finance transparency, when compared to policy differences, suggest that transparency is more of a valence attribute than a partisan one.

Figure 8 shows AMCEs by ideology, testing H4b. Here we see that even if respondents, on average, treat transparency and compliance as valence issues, ideological extremists react differently to over-compliance, providing mixed support for H4b. Extreme liberals are most affected by noncompliance $(-0.21[-0.28$, $-0.14]$ ), but also least impressed by over-compliance $(-0.06[-0.13,0.01])$, all measured relative to "mere" compliance. Extreme conservatives deviate from extreme liberals when it comes to noncompliance $(-0.03[-0.11,0.05])$, suggesting that attitudes toward compliance with campaign finance laws could be driven by ideology among extremists (Appendix 9A); however, the estimated differences in marginal means are not statistically significant (Appendix 9B). Extremists on both sides prefer candidates who discouraged dark money $(0.08[0.02,0.14]$ for liberals, $0.11,[0.04,0.18]$ for conservatives), to candidates with dark money support. This suggests that transparency is a valence issue even among extremists. 
Table 5 Summary of results. $\mathrm{H} 1 \mathrm{a}, \mathrm{H} 2 \mathrm{~b}, \mathrm{H} 4 \mathrm{a}$, and $\mathrm{H} 4 \mathrm{~b}$ are tested in both experiments. $\mathrm{H} 1 \mathrm{~b}, \mathrm{H} 2 \mathrm{a}, \mathrm{H} 3$, and $\mathrm{H} 3 \mathrm{~b}$ are tested in Study 2

\begin{tabular}{|c|c|}
\hline Hypothesis & Supported? \\
\hline $\begin{array}{l}\text { H1a: Respondents will punish candidate relation- } \\
\text { ships to dark money }\end{array}$ & $\begin{array}{l}\text { Yes, though respondents in study } 2 \text { punished both } \\
\text { dark money relationships equally }\end{array}$ \\
\hline H1b: Respondents punish noncompliance & Study 2: Yes \\
\hline $\begin{array}{l}\text { H2a: Respondents reward candidates who do not } \\
\text { have / discourage dark money support }\end{array}$ & Study 2: Yes \\
\hline $\mathrm{H} 2 \mathrm{~b}$ : Respondents reward over-compliance & $\begin{array}{l}\text { Study 1: Yes } \\
\text { Study 2: Yes, when pooled, marginally when not } \\
\text { pooled (map on site is rewarded, small donor } \\
\text { percentage not) }\end{array}$ \\
\hline $\begin{array}{l}\text { H3a: Uncertainty hypothesis-estimates in } \mathrm{H} 1 \text { and } \\
\mathrm{H} 2 \text { do not decrease as ideological or policy dis- } \\
\text { tance increases between respondent and candidate }\end{array}$ & Study 2: Yes \\
\hline $\begin{array}{l}\text { H3b: Policy trumps valence_-estimates in } \mathrm{H} 1 \text { and } \\
\mathrm{H} 2 \text { decrease as ideological or policy distance } \\
\text { increases between respondent and candidate }\end{array}$ & Study 2: No \\
\hline $\begin{array}{l}\text { H4a: rewards [punishments] among Democratic } \\
\text { respondents are larger than rewards [punishments] } \\
\text { among Republican respondents }\end{array}$ & $\begin{array}{l}\text { Marginally in both studies, though Study } 2 \text { makes } \\
\text { clear that the differences around dark money are } \\
\text { small relative to policy-related differences }\end{array}$ \\
\hline $\begin{array}{l}\text { H4b: Ideological extremists react differently from } \\
\text { each other to transparency information (a partisan } \\
\text { issue), whereas ideological moderates react simi- } \\
\text { larly to each other (a valence issue) }\end{array}$ & $\begin{array}{l}\text { Study 1: No } \\
\text { Study 2: Moderates react similarly, treating } \\
\text { compliance as valence; extremists' AMCEs were } \\
\text { different from each other for compliance, but } \\
\text { similar for disclosure; marginal means indistin- } \\
\text { guishable }\end{array}$ \\
\hline
\end{tabular}

In sum, Study 2 suggests that more moderate respondents treat transparency and compliance as valence issues, whereas ideological extremists may disagree about the importance of compliance. Inconsistent extremist responses to candidates' relationships to dark money groups deserve further study.

Table 5 summarizes the results. In general, respondents reward transparency and compliance and punish their lack. That they do so even in the face of policy differences is a somewhat surprising result, given other findings in the policy-valence literature. Politically extreme voters react differently from each other when it comes to compliance, but not transparency. With regards to transparency, extremists and moderates reacted similarly, equating raising dark money with receiving dark money support, and rewarding candidates that discourage dark money. Extremists' compliance reactions do not follow expectations. Extreme conservatives were most rewarding of over-compliance, and extreme liberals were least rewarding, relative to baseline. Ideological extremists' attitudes toward legal compliance merit further study. 


\section{Discussion}

We can put these results in context by comparing them to the literature on the negative favorability effects of political ads. Candidates who run negative ads generally experience backlash for doing so (Ridout et al., 2015). The backlash to a negative ad run by a dark money group (Rhodes et al., 2019) or other outside groups (Dowling \& Wichowsky, 2015) is 11-13 points. These point estimates are similar in magnitude to the punishment for noncompliance shown here, though these estimates should be understood relative to the reference category chosen.

In most specifications, respondents rewarded transparency less than they punish dark money support. Behavioral economists and psychologists have long documented asymmetry between reward and punishment (Fehr \& Gachter, 2000; c.f. Wang \& Leung, 2010). Nevertheless, the size of the punishment of Johnson in Study 1 is striking. Respondents' reactions here are similar to those by respondents in related studies in which coordination between outside groups and campaigns may be assumed by respondents (Brown \& Martin, 2015; Spencer \& Theodoridis, 2020).

Perceived trustworthiness may explain the results. We know from prior research that trustworthiness evaluations can be a strong predictor of vote choice (Parker, 1989; Levi \& Stokes, 2000) and that trust is correlated with other important aspects of political communication in the campaign finance context, like the persuasiveness of candidate speech (Goovaerts \& Marien, 2020). Candidates who are not very persuasive may be seen as less trustworthy on the trustworthiness dimension that Levi and Stoker (2000) identify as "competence in the domain over which trust is being given." In our campaign finance context, prior work suggests that trust increases when under-disclosure is not pointed out. Specifically, political ad sponsors who do not disclose their donors, but whose lack of disclosure is not highlighted for respondents, are perceived to be more trustworthy than candidate campaigns running ads with the required disclaimer (Ridout et al., 2015). Studies 1 and 2 ask about candidate trustworthiness in the context of campaign finance transparency. In Study 1, treatment group respondents rated Johnson as almost 4 percentage points less trustworthy than control group respondents $(-3.9[-7.35,-0.37])$. Conversely, Conley was rated 8.9 [5.28, 12.59] percentage points more trustworthy among respondents in the treatment group (Appendix 10A). In Study 2, noncompliance caused a decrease in a five-point trustworthiness rating $(-0.24[-0.29$, $-0.19]$ for missed deadlines, and -0.28 [ $-0.33,-0.23]$ for reporting gaps). Discouraging dark money causes an increase in the rating of 0.13 [0.10, 0.17]. Overcompliance causes an increase in trust rating $(0.04[-0.01,0.09]$ for including the percent of small donors on the website, and 0.04 [0.00, 0.09] for a map of donor locations) (Appendix 10B).

Trustworthiness is only one possible mechanism of the vote choice results. Other inferences were possible. For example, due to the primary context, respondents may have electability concerns that interact with candidate transparency. More transparent candidates may be viewed as more electable by voters. Similarly, engagement with political news may help explain some of these effects. In Appendix 11, readers 
can observe that high news engagement respondents drive the reward for discouraging dark money. These are areas for future research.

Survey experiments may be our best chance to study voter decision-making in the face of campaign finance transparency and compliance information. Nevertheless, this common methodology has limitations (Mutz \& Kim, 2020). Survey experiments cannot replicate the voting booth experience. Information provided to respondents is not available on the ballot itself. It may be available on devices the voters carry into the booth, though we should not assume that voters access the information while voting.

This study should be understood in context. Respondents had less income, on average, than the average American. Income correlates with the likelihood of donating (Barber et al., 2017); lower income people may especially value transparency, which allows them to understand the source of the money behind the campaigns they see but cannot contribute to.

\section{Conclusion}

Campaign finance regulatory compliance may be the only compliance task that campaigns undertake on a near-constant basis during the campaign. The results in the studies presented here suggest that compliance information is important to voters: the average marginal effect of information related to non-compliance is larger than most valence characteristics analyzed, aside from having a weak grasp of the issues. Compliance is important, and it should be brought into our discipline's analysis of candidates and campaigns for more than the scandals that may emerge in its absence.

Before this study, we didn't know whether voters treat campaign finance transparency as policy or valence. The similarity of the estimates in Study 2 across parties, when compared to differences on policy issues, suggests that transparency is a valence issue. Respondents generally preferred candidates who comply with campaign finance disclosure laws to those who don't, and they preferred candidates who distance themselves from dark money groups to those who receive the groups' support. These preferences are consistently apparent across party and ideology groups, though ideological extremists diverge on the importance of legal compliance. Preferences around transparency and compliance are also largely robust to policy preference mismatches between the candidate and respondent. While the differences between Republicans and Democrats in reacting to campaign finance disclosure information are smaller than their policy differences, they are larger than the differences between partisans in other valence-related attributes offered to respondents, such as the percent of small donors or the ability to be persuasive in public. 
These experiments were designed specifically to test the effects of campaign finance transparency and compliance signaling in party primaries. Transparency and compliance have also arisen as important issues in non-partisan electoral contexts (local elections, judicial elections), though the non-partisan context is not presented here. ${ }^{16}$ Rhodes et al. (2019) find that the negative effects of dark money support persist in the general election context, though they are somewhat muted. Wood and Grose (2021) also find that voters punished noncompliance in the general election context in their study of randomized FEC audits following the 1976 election. However, to react to campaign finance information, voters must have it. We know that, like most issue areas, voters' baseline knowledge of campaign finance is not high. These studies show us that when voters are provided information, they make different choices than when they lack it, and they do so even when the information is presented along with policy information.

The scope of the informational benefit is important for our campaign finance regulation and jurisprudence (Wood, 2021). These results can help judges to broaden their understanding of disclosure laws facing constitutional challenges. Respondents who have campaign finance transparency information make different choices, on average, than those who lack it, as we observe in Study 1. Study 2 helps us observe the importance that voters place on campaign finance information even when confronted with other information, including policy information. Respondents changed their trustworthiness ratings of the candidates based on their campaign finance transparency, suggesting that voters use campaign finance transparency to learn about candidate traits (Appendix 10).

To improve voter information, states may decide to require "nondisclosure disclosure," in which advertisements run by dark money groups disclose that the advertisement was paid for by anonymous donors on the face of the ad (Gerken et al., 2014). These findings also suggest fruitful avenues for political messaging, such as running ads to point out prior noncompliance by opponents. Candidates may also want to brag about their own over-compliance, though with modest expectations of how many voters they can win over with that strategy. Finally, because respondents did not calibrate their responses to violations, these findings suggest that regulators should calibrate enforcement accordingly, so as not to bring heavy public sanction on relatively minor noncompliance.

Supplementary Information The online version contains supplementary material available at https://doi. org/10.1007/s11109-022-09776-4.

Acknowledgements This work benefitted from helpful conversations with and feedback from Teresa Delgado (who also provided time and space to work during a pandemic), Sam Erman, Mike Gilbert, Benjamin Graham, Christian Grose, Jake Grumbach, Gillian Hadfield, Erin Hartman, Daniel Klerman, Morris Levy, Dan Simon, Doug Spencer, Alex Theodoridis, seminar participants at Pepperdine and USC, conference participants at the 2017 CCES Conference and 2019 meeting of the Midwest Political Science Association, my fellow members of the Federal Bipartisan Campaign Finance Task Force, and members

\footnotetext{
16 Whether these results would hold in a nonpartisan election is an interesting avenue for future research. Because these findings exist in the partisan primary context, and that compliance effects (Wood \& Grose 2021) and dark money effects (Rhodes et al., 2019) are still detectible in the partisan general election context, it's possible that these results would also extend to the context of nonpartisan elections.
} 
of the Google policy team. Raquel Centeno, Dara O'Neill, Oliver Wu, Danielle Stierna, Mimi Sanicola, Rachel Abanonu, John Lee, and Matthew Palmquist provided excellent research assistance. I gratefully acknowledge support from the Hewlett Foundation, Democracy Fund, and California Forward. Pre-analysis plan available at: https://egap.org/registration/5188 and in Appendix; replication data and code available at: https://doi.org/10.7910/DVN/TA4DUW.

Funding Funding was supported by William and Flora Hewlett Foundation (US), Democracy Fund, California Forward.

Open Access This article is licensed under a Creative Commons Attribution 4.0 International License, which permits use, sharing, adaptation, distribution and reproduction in any medium or format, as long as you give appropriate credit to the original author(s) and the source, provide a link to the Creative Commons licence, and indicate if changes were made. The images or other third party material in this article are included in the article's Creative Commons licence, unless indicated otherwise in a credit line to the material. If material is not included in the article's Creative Commons licence and your intended use is not permitted by statutory regulation or exceeds the permitted use, you will need to obtain permission directly from the copyright holder. To view a copy of this licence, visit http://creativecommons.org/licen ses/by/4.0/.

\section{References}

Adams, J., Merrill, S., III., Simas, E. N., \& Stone, W. J. (2011). When candidates value good character. Journal of Politics, 73(1), 17-30.

Ansolabehere, S., \& Snyder Jr., J. M. (2000). Valence politics and equilibrium in spatial election models. Public Choice, 103, 327-336.

Barari, S., Berwick, E., Hainmueller, J., Hopkins, D, Liu, S., Strezhnev, A., \& Yamamoto, T. “cjoint: AMCE Estimator for Conjoint Experiments, Version: 2.1.0.”

Barber, M. J., Canes-Wrone, B., \& Thrower, S. (2017). Ideologically sophisticated donors. American Journal of Political Science, 61(2), 271-288.

Basinger, S., Brown, L., Harris, D. B., \& Gulati, G. (2014). Counting and classifying congressional scandals. In A. Danges, \& M. Sachleben (Eds.), Scandal! Bloomsbury Academic.

Bianco, W. T. (1994). Trust: Representatives and constituents. University of Michigan Press.

Brown, R. L., \& Martin, A. D. (2015). Rhetoric and reality. NYU Law Review, 90(4), 1066-1094.

Dowling, C. M., \& Wichowsky, A. (2013). Does it matter who's behind the curtain? American Politics Research, 41(6), 965-996.

Dowling, C. M., \& Wichowsky, A. (2015). Attacks without consequences. American Journal of Political Science, 59(1), 19-36.

Druckman, J. N., \& Kam, C. D. (2011). Students as experimental participants. In J. N. Druckman, D. P. Green, J. H. Kuklinski, \& A. Lupia (Eds.), Cambridge handbook of experimental political science. Cambridge University Press.

Fehr, E., \& Gächter, S. (2000). Fairness and retaliation. Journal of Economic Perspectives, 14(3), $159-181$.

Franchino, F., \& Zucchini, F. (2015). Voting in a multi-dimensional space: A conjoint analysis employing valence and ideology attributes of candidates. Political Science Research and Methods, 3(2), 221-241.

Gaskins, B., Seljan, E., Lochner, T., Kowal, K., Dundon, Z., \& Gold, M. (2019). From the FEC to the Ballot Box. American Politics Research., 47(5), 1000-1035.

Gerber, A. S., Huber, G. A., Doherty, D., Dowling, C. M., \& Hill, S. J. (2013). Do perceptions of ballot secrecy influence turnout? American Journal of Political Science, 57(3), 537-551.

Gerken, H.K., Gibson, W., \& Lyons, W. (2014). Rerouting the flow of 'dark money' into political campaigns. Washington Post April 3, 2014, https://www.washingtonpost.com/opinions/rerouting-theflow-of-dark-money-into-political-campaigns/2014/04/03/1517ac6e-b906-11e3-9a05-c739f29ccb 08_story.html 
Gilbert, M. (2013). Campaign finance disclosure and the information tradeoff. Iowa Law Review, 98(4), 1847-1894.

Goovaerts, I., \& Marien, S. (2020). Uncivil communication and simplistic argumentation. Political Communication, 37(6), 768-788.

Hainmueller, J., Hopkins, D. J., \& Yamamoto, T. (2014). Causal inference in conjoint analysis. Political Analysis, 22(1), 1-30.

Horiuchi, Y., Smith, D., \& Yamamoto, T. (2018). Measuring voters' multidimensional policy preferences with conjoint analysis: Application to Japan's 2014 election. Political Analysis, 26(2), 190-209. https://doi.org/10.1017/pan.2018.2.

Kirkland, P., \& Coppock, A. (2017). Candidate choice without party labels. Political Behavior, 40(3), 571-591.

Leeper, T., Hobolt, S., \& Tilley, J. (2020). Measuring subgroup preferences in conjoint experiments. Political Analysis, 28(2), 207-221.

Levi, M., \& Stoker, L. (2000). Political trust and trustworthiness. Annual Review of Political Science, 3 , $475-507$.

Lupia, A. (1994). Shortcuts versus encyclopedias. American Political Science Review, 88(1), 63-76.

Lupia, A., \& McCubbins, M. (1998). The democratic dilemma. University of Cambridge Press.

Malhotra, N., \& Krosnick, J. A. (2007). The effect of survey mode and sampling on inferences about political attitudes and behavior. Political Analysis, 15(3), 286-324.

McCurley, C., \& Mondak, J. J. (1995). The influence of incumbents' competence and integrity in U.S. house elections. American Journal of Political Science, 39, 864-885.

Mondak, J. J. (1995). Nothing to read. University of Michigan Press.

Mummolo, J., \& Nall, C. (2017). Why partisans do not sort. The Journal of Politics, 79(1), 45-59.

Mutz, D., \& Kim, E. (2020). The progress and pitfalls of using survey experiments in political science. Oxford Research Encyclopedia of Politics.

Oklobdzija, S. (2019). Public positions, private giving. Research \& Politics. 1-8.

Page, B. I., \& Jones, C. C. (1979). Reciprocal effects of policy preferences, party loyalties and the vote. American Political Science Review, 73(4), 1071-1089.

Parker, G. R. (1989). The role of constituent trust in congressional elections. Public Opinion Quarterly, $53,175-196$.

Piotrowski, S. J., \& Van Ryzin, G. G. (2007). Citizen attitudes toward transparency in local government. American Review of Public Administration, 37(3), 306-323.

Rhodes, S. C., Franz, M. M., Franklin Fowler, E., \& Ridout, T. N. (2019). The role of dark money disclosure on candidate evaluations and viability. Election Law Journal, 18(2), 175-190.

Ridout, T. N., Franz, M. M., \& Franklin Fowler, E. (2015). Sponsorship, disclosure, and donors. Political Research Quarterly, 68(1), 154-166.

Roelofs, P. (2019). Transparency and mistrust: Who or what should be made transparent? Governance, 32(3), 565-580.

Rogowski, J. C., \& Sutherland, J. L. (2016). How ideology fuels affective polarization. Political Behavior, 38(2), 485-508.

Sen, M. (2017). How political signals affect public support for judicial nominations. Political Research Quarterly, 70(2), 374-393.

Simas E. (2021). Extremely high quality? How ideology shapes perceptions of candidates' personal traits. Public Opinion Quarterly, 84(3), 669-724.

Spencer, D. M., \& Theodoridis, A. G. (2020). Appearance of corruption: Linking public opinion and campaign finance reform. Election Law Journal, 19, 510.

Stokes, D. E. (1963). Spatial models of party competition. American Political Science Review, 57(2), 368-377.

Stone, W. J., \& Simas, E. N. (2010). Candidate valence and ideological positions in U.S. house election. American Journal of Political Science, 54(2), 371-388.

Tomz, M., \& Van Houweling, R. P. (2008). Candidate positioning and voter choice. American Political Science Review, 102(3), 303-318.

Wang, C. S., \& Leung, A. K. (2010). The cultural dynamics of rewarding honesty and punishing deception. Personality \& Social Psychology Bulletin, 36(11), 1529-1542.

Wittman, D. (2005). Valence characteristics, costly policy, and the median-crossing property. Public Choice, 124(3-4), 365-382.

Wood, A. K. (2018). Campaign finance disclosure. Annual Review of Law and Social Science, 14, 11-27. 
Wood, A. K. (2021). Learning from campaign finance information. Emory Law Journal, 70(5), 1091-1142.

Wood, A. K., \& Grose, C. R. (2021). Campaign finance transparency affects legislators' election outcomes and behavior. American Journal of Political Science.

Wood, A. K., \& Ravel, A. M. (2018). Fool me once: Regulating fake news and other online advertising. Southern California Law Review, 91(6), 1223-1278.

Wright, M., Levy, M., \& Citrin, J. (2016). Public attitudes towards immigration policy across the legal/ illegal divide. Political Behavior, 38(1), 229-253.

Zaller, J. (1992). The nature and origins of mass opinion.

Publisher's Note Springer Nature remains neutral with regard to jurisdictional claims in published maps and institutional affiliations. 